\title{
Jean-Baptiste Charcot, the French Antarctic expedition and scurvy
}

\author{
Jean-Baptiste Charcot, expedição Antártica e escorbuto \\ Hélio Afonso Ghizoni Teive ${ }^{1}$, Francisco Manoel Branco Germiniani ${ }^{1}$, Renato Puppi Munhoz ${ }^{2}$
}

\begin{abstract}
During the second expedition to the South Pole, Commander Jean-Baptiste Charcot and some members of the crew of "Pourquoi Pas?" developed symptoms suggestive of scurvy. The clinical picture was totally reversed after dietary changes.
\end{abstract}

Keywords: scurvy, vitamin C, maritime explorer.

RESUMO

Durante a segunda expedição polar do sul, o comandante Charcot e alguns membros da tripulação do "Porquoi Pas?" desenvolveram sintomas sugestivos de escorbuto. O quadro clínico foi totalmente reversível após modificações da dieta.

Palavras-chave: escorbuto, vitamina C, explorador marítimo.

Jean-Baptiste Charcot (1867-1936), Professor Jean-Martin Charcot's son and a former neurologist who became a worldrenowned maritime explorer known as Commander Charcot, took part in several French Antarctic expeditions ${ }^{1}$. During the second and last expedition to the South Pole, Jean-Baptiste Charcot and some members of the crew developed symptoms suggestive of scurvy ${ }^{2}$. The aim of this paper is to review the original description of this problem in the journal of the second French expedition to the South Pole between 1908 and 1910 (Voyage of the Pourquoi Pas?).

\section{THE FRENCH EXPEDITION TO THE SOUTH POLE}

The first Antarctic expedition took place between 1903 and 1905, and the second between 1908 and 1910. After the first expedition, which sailed on the ship Français, Jean-Baptiste Charcot became very famous and became known as Commander Charcot ${ }^{1,2}$. Following the second expedition, he published the report entitled The Voyage of the Pourquoi Pas?, which gained widespread renown and was considered the journal of the expedition ${ }^{1,2}$ (Figure). In August 1909, Charcot, who was head of the expedition and commander of the Pourquoi Pas?, became very anxious because part of his crew was developing symptoms of intense weakness and foot edema, symptoms which he also developed after a few days².

\section{COMMANDER CHARCOT, THE CREW OF POURQUOI PAS? AND SCURVY}

In June 1909, during the winter, some crew members of the Pourquoi Pas? began to complain of muscle pains, which were considered to be rheumatic due to the extreme weather conditions ${ }^{2}$. Then Godfroy, the sub-lieutenant, and Dr. Liouville, the assistant doctor of the expedition, became very pale and asthenic, with violent muscle pains and severe swelling of the legs. Charcot also began to suffer from shortness of breath, intense fatigue, pains and swollen legs, and diagnoses of "polar anemia", "polar myocarditis" and even scurvy were considered ${ }^{2}$. When his condition deteriorated, Charcot decided that he was suffering from pronounced myocarditis and abandoned the idea of scurvy because there were none of the classical symptoms of the disease. The condition of those affected worsened significantly in the following three months, and Godfroy and Charcot developed hand ulcerations, intense muscle weakness, severe pains, palpitations, cardiac arrhythmia, pulse irregularities and finally purpura. No gum lesions were described ${ }^{2}$. Charcot came to

${ }^{1}$ Serviço de Neurologia, Departamento de Medicina Interna, Hospital de Clínicas, Universidade Federal do Paraná, Curitiba PR, Brazil;

${ }^{2}$ Movement Disorders Centre, Toronto Western Hospital, University of Toronto, Toronto ON, Canada.

Correspondence: Hélio Afonso Ghizoni Teive; Rua General Carneiro, 1103/102 Centro; 80060-150 Curitiba PR, Brasil; E-mail: hagteive@mps.com.br

Conflicts of interest: There is no conflict of interest to declare.

Received 02 March 2014; Received in final form 15 March 2014; Accepted 04 April 2014. 


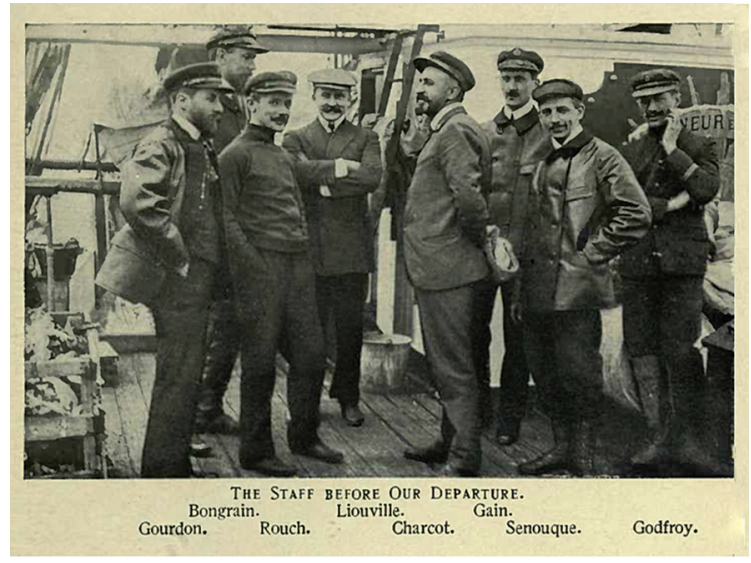

Extracted from reference 2

Figure. The French Expedition to the South Pole: Commander Charcot and his crew.

the conclusion that they were suffering from scurvy or, more precisely, preserved-food sickness. He therefore decided to remove all preserved meat from their diet and to eat only seal, penguin, garlic, sauerkraut and jam. The crew members were also taking considerable quantities of citric acid and looking for seals, penguins and other birds's. By the end of September their clinical condition improved, and Charcot felt that what they had been suffering from for more than three months was preserved-food sickness ${ }^{2}$. His conclusion was that the so-called polar anemias were in fact nothing more than maladies associated with scurvy ${ }^{2}$. He stated that,

In the past, when crews lived almost entirely on salt meat they were attacked by the well-known variety of scurvy, with large black spots, ulceration of the gums, etc. But everything changes, even diseases, and with the modern preserved food the classical scurvy has been replaced by the curious kind from which we suffered, characterized especially by oedema of the lower limbs and myocarditis, without anything wrong with the gums. Something of the kind, moreover, showed itself in our Army during the Crimean War. Seals, fortunately, are again abundant and we can kill more than we require for our food supply. On board the Discovery there was also a serious outbreak of scurvy, much more classical in its nature than ours, which was rapidly and completely got rid of by using the flesh of these animals ${ }^{2}$.

On October 8, Charcot wrote in his diary that the disease had been completely cured by eliminating preserved foods and adding fresh meat to their diet ${ }^{2}$. Interestingly, Charcot did not mention in his diary the seminal paper published in 1753 by Sir James Lind, a Scottish naval surgeon, describing the effective treatment of scurvy with citrus fruits ${ }^{3}$. The British Navy used this approach to prevent and cure scurvy, and the incidence of the disease declined during the $18^{\text {th }}$ century $^{3}$. Nevertheless, it was only later that the relationship between scurvy and vitamin $\mathrm{C}$ deficiency was proved. Although scurvy was traditionally considered "a plague of the sailor", the condition also affects soldiers (on military rations), the chronically ill, the elderly, smokers, alcoholics and patients with sepsis in intensive care units ${ }^{4,5,6}$. Schleicher et al. published an interesting study in 2009 on serum vitamin $\mathrm{C}$ and the prevalence of vitamin $\mathrm{C}$ deficiency in the USA, in which they showed that $7.1 \%$ of healthy middle-class participants were vitamin C-deficient and 13.7\% vitamin C-depleted ${ }^{7}$. Similar results were obtained in the UK by Mosdol et al., who reported in a study in 2008 that $25 \%$ of men and $16 \%$ of women from the UK's low-income population were vitamin C-deficient ${ }^{8}$. More recently, arginine and other amino acids were found to have a synergistic role, complementing the effect of vitamin $\mathrm{C}$ in the treatment of critically ill sailors with scurvy9.

\section{CONCLUSION}

During the second French expedition to the South Pole, Jean-Baptiste Charcot and some members of his crew developed symptoms suggestive of scurvy. The clinical picture was totally reversible after dietary modifications.

\section{References}

1. Teive HAG, Munhoz RP, Simões JC. Charcot's son, commander Jean-Baptiste Charcot: from neurology to "Porquoi Pas?" Arq Neuropsiquiatr 2012;70:305-307.

2. Charcot JB. The voyage of the 'Why Not?' The Journal of the second French South Polar Expedition, 1908-1910. (Translation by Philip Walsh). University of Toronto Library, The Musson Book Company Limited, 1980.

3. Smith A, Di Primio G, Humphrey-Murto S. Scurvy in the developed world. CMAJ 2011;183:E752-E7555.

4. Baron JH. Sailors' scurvy before and after James Lind - a reassessment. Nutr Rev 2009;67:315-332.

5. Bohrer I, Roy M, Nager W, te Wildt B, Emrich HM, Ohlmeier O. MD. Scurvy - a wrongly forgotten avitaminosis. MMW Fortschr Med 2007;149:41-43.
6. Wilson N, Nghiem N, Summers JA, Carter MA, Harper G. A nutritional analysis of New Zealand military food rations at Gallipoli in 1915: likely contribution to scurvy and other nutrient deficiency disorders. N Z Med J 2013:266:12-29.

7. Schleicher RL, Carroll MD, Ford ES, et al. Serum vitamin C and the prevalence of vitamin C deficiency in the United States: 2003-2004 National Health and Nutrition Examination Survey (NHANES). Am J Clin Nutr 2009;90:1252-1263.

8. Mosdol A, Erens B, Brunner EJ. Estimated prevalence and predictors of vitamin C deficiency within UK's low-income population. J Public Health 2008;30:456-460.

9. Durzan DJ. Arginine, scurvy and Cartier's "tree of life". J Ethnobio Ethnomed 2009:5:5 doi: 10.1186/1786-4269-5-5. 